Cornell Law Library

Scholarship@Cornell Law: A Digital Repository

Cornell Law Faculty Publications

Faculty Scholarship

$11-1-1997$

\title{
How Efficient Markets Undervalue Stocks: CAPM and ECMH under Conditions of Uncertainty and Disagreement
}

Lynn A. Stout

Cornell Law School,1s483@cornell.edu

Follow this and additional works at: http://scholarship.law.cornell.edu/facpub

Part of the Banking and Finance Commons, and the Securities Law Commons

\section{Recommended Citation}

Stout, Lynn A., "How Efficient Markets Undervalue Stocks: CAPM and ECMH under Conditions of Uncertainty and Disagreement" (1997). Cornell Law Faculty Publications. Paper 447.

http://scholarship.law.cornell.edu/facpub/447

This Article is brought to you for free and open access by the Faculty Scholarship at Scholarship@Cornell Law: A Digital Repository. It has been accepted for inclusion in Cornell Law Faculty Publications by an authorized administrator of Scholarship@Cornell Law: A Digital Repository. For more information, please contact jmp8@cornell.edu. 


\title{
HOW EFFICIENT MARKETS UNDERVALUE STOCKS: CAPM AND ECMH UNDER CONDITIONS OF UNCERTAINTY AND DISAGREEMENT
}

\author{
Lynn A. Stout*
}

In 1988, the Wall Street Journal began a contest. ${ }^{1}$ Periodically, the Journal staff would invite four professional money managers to select the stocks they thought would do best in the coming months. Then the staff would repair to a nearby tavern, pin a page from the stock quotes section to the wall, and throw darts to select their own portfolio. At the end of each contest period, the Journal would announce who had done better, the pros or the darts. In the first round, the hands-down winner of this "Investment Dartboard" contest was: the darts. ${ }^{2}$

This result came as no surprise to either finance theorists or their hangers-on. ${ }^{3}$ After all, we had all studied from that bible of modern financial theory, Brealey and Myers' Principles of Corporate Finance. ${ }^{4}$ We knew that decades of scholarship had definitively proven the Efficient Capital Markets Hypothesis (ECMH), a keystone theory of modern finance that predicts that market prices are "informationally efficient" (i.e., respond to new information almost instantaneously). ${ }^{5}$ We also knew about the Capital Asset Pricing Model (CAPM), a second fundamental tenet of finance that holds that rational investors value stocks according only to their expected return and nondiversifiable risk. ${ }^{6}$ Taken together, the ECMH and CAPM seemed to teach that prices set by an efficient market reflect the best possible estimates of stocks' future risks and returns, with the logical implication that any attempt to

* Professor of Law, Georgetown University Law Center.

1 See John R. Dorfman, Investment Dartboard: Pros Gamely Go up Against 'Dartboard', WALL Sr. J., Oct. 4, 1988, at C1.

2 John R. Dorfman, Investment Dartboard: Random Stock Picks Give Pros the Woes, Wall ST. J., Nov. 4, 1988, at Cl (reporting that in the first month of the contest, the dartboard portfolio had risen $0.7 \%$ while the pros' choices declined an average of $2.5 \%$ ).

3 I fit myself into this second category, along with many other corporate and securities scholars.

4 Richard A. Brealey \& Stewart C. Myers, Principles of Corporate Finance (5th ed. 1996).

5 See generally id. at 336-37.

6 See generally id. at 143-65. 
identify underpriced or overpriced stocks was doomed to failure. Thus the Investment Dartboard results only confirmed what the academics already knew: you can't beat the market. ${ }^{8}$

Or so it seemed from the first round. Undeterred by their initial defeat, investment managers continued to step up to the plate in subsequent Investment Dartboard contests. And as the contest continued, it soon became apparent that while the pros sometimes lost, more often they won. The Journal has now run the Investment Dartboard contest for over eight years, and over that time a clear pattern has emerged: although the darts frequently give the pros a drubbing, on average the pros are beating both the darts and the market. Indeed, as of October 1996, the pros' portfolios had produced average annual gains of $20.6 \%$, compared to $11.2 \%$ for the darts, and $11.6 \%$ for the Dow Jones Industrial Average. ${ }^{9}$

What can explain this peculiar (to academics) result? ${ }^{10}$ One possibility is that the Investment Dartboard contest offers a striking illustration of the so-called "hot hands" effect. Extensive empirical evidence supports the claim that fund managers who actively trade stocks tend, on average, to underperform the market. ${ }^{11}$ Yet the evidence also suggests that those few managers who do beat the market-the winning traders with hot hands-have a statistically greater chance of doing so again in the next period. ${ }^{12}$ In other words, although most fund managers don't beat the market's return, those who do seem to be able to beat it with some

7 As Professors Brealey and Myers put it, efficient market theory teaches that investors should "trust market prices," because "in an efficient market there is no way for most investors to achieve consistently superior rates of return." Id. at 336-37. An exception to this general rule may exist for investors who have access to proprietary corporate information. There is some evidence that stock prices do not fully reflect such "inside" information. See generally id. at 295. However, there seems to be little to suggest that Berkshire Hathaway's success can be attributed to insider information.

8 I suspect one reason why academics have found this result so attractive is that it gives us a quick comeback to that annoying question, "If you're so smart, why aren't you rich?"

9 See Georgette Jasen, Investment Dartboard: Luck Out: Stock Experts Top the Darts, WALL ST. J., Oct. 9, 1996, at C1 (reporting that during eight years of contest, pros' portfolios produced average six-month gains of $10.3 \%$, compared to $5.6 \%$ for dart portfolio and $5.8 \%$ for the Dow Jones Industrial Average).

10 Although I am unaware of any attempt to test the Investment Dartboard contest results for statistical significance, the pros' success has been quite marked and has persisted over a period of several years.

11 Edwin J. Elton, et al., The Persistence of Risk-Adjusted Mutual Fund Performance, 69 J. Bus. 133 (1996). This result is obvious once one realizes that the secondary stock market is largely composed of such traders, and that trading involves transactions costs.

12 See id. at 135 (surveying literature). See also, e.g., Darryll Hendricks, et al., Hot Hands in Mutual Funds: Short Run Persistence of Relative Performance, 1974-1988, $48 \mathrm{~J}$. FIN. 93 (1993). 
consistency. Under the rules of the Investment Dartboard contest, the two pros whose stock picks do best in each period are invited back for another round against the darts. ${ }^{13}$ Winners continue to play, while losers exit the game. Thus, the contest rules favor the continued participation of hot hands traders. ${ }^{14}$

The hot hands phenomenon poses a serious challenge to conventional finance. Because stocks are volatile instruments, it should come as no surprise that some managed portfolios outperform the overall market during a particular period while other portfolios lag behind. Yet, according to the ECMH/CAPM, the identity of the winners and losers should be a matter of random luck. The idea that a small number of hot hands traders can consistently identify and profit from mispriced securities shakes the very foundations of the efficient markets claim that "the market knows best."

Two of the hottest pairs of hands around, of course, belong to Warren Buffett and his partner, Charlie Munger. Over a period of decades, these two individuals have demonstrated consistently superior performance in picking stocks for Berkshire Hathaway. ${ }^{15}$ As a result, their very existence has become something of an embarrassment to a generation of finance theorists and corporate scholars. Messrs. Buffett and Munger not only say they can beat the market: they do. What are we academics to make of them?

\section{Postmodern Financial Theory}

If we can't beat them in proving that they can't beat the market, perhaps we should give some thought to joining them. In this vein, recent years have seen the rise of a new generation of finan-

\footnotetext{
13 See Jasen, supra note 9, at C1.

14 Other possible explanations exist as well. For example, Professor Burton Malkiel has suggested that the publicity surrounding the Investment Dartboard contest may produce short-term gains for the stocks recommended by the pros. See Dorfman, supra note 1, at C1. However, using the conventional ECMH/CAPM approach, it is difficult to see why publicity alone should affect a stock's price, if an efficient market has already priced it accurately. See infra text accompanying note 36 (discussing publicity and prices of neglected firms). Another possibility is that the stocks selected by the pros carry a higher degree of nondiversifiable (or beta) risk than the market as a whole, and so offer higher returns to compensate for that risk. See infra note 23 (discussing relationship between beta risk and return under CAPM). However, I am unaware of any evidence that would support the claim that the pro's portfolios carry higher betas than the market. See also infra text accompanying notes $40-42$ (discussing empirical evidence that, contrary to CAPM, stocks with high levels of beta risk may not offer higher returns).

15 See Roger Lowenstein, Modern-day Midas, Bus. Times, Mar. 9, 1996, at 2 (reporting that over the past four decades Warren Buffett has earned annual gains of $28.6 \%$, while major stock averages have enjoyed annual gains of about $10 \%$ ).
} 
cial theorists and securities scholars who take "modern" finance theory a la Brealey and Myers with a very large portion of salt. These "postmodern" 16 scholars have produced a number of theoretical alternatives to the standard ECMH/CAPM that support what Buffett, Munger, and others who make their livings in the market have been telling us all along: contrary to the central tenets of modern finance theory, market price does not necessarily reflect the best estimate of a stock's value.

Scholars willing to explore the brave new world of postmodern finance will find an expanding literature that offers at least three exciting new avenues of investigation. One is so-called "noise trading" theory. Noise theorists postulate that a substantial portion of traders in the market are irrational, in the sense that they suffer testable cognitive biases that impede their collective ability to coldly calculate the intrinsic value of securities. Because noise traders act on psychological impulse ("noise") rather than true information, their trading tends to drive stock prices away from best estimates of fundamental values, creating opportunities for rational traders to identify underpriced and overpriced securities. ${ }^{17}$

A second important branch of the new literature has been dubbed "chaos" (or, sometimes, "rational bubble" or "sunspot") theory. Chaos finance explores scenarios where a small deviation of an asset's market price from its intrinsic value may be magnified through self-reinforcing cascade effects into wild and fundamentally unjustified price swings. ${ }^{18}$ Thus, like noise theory, chaos finance also suggests that efficient market prices sometimes fail to reflect best estimates of value.

16 I owe this appellation to Professor Lawrence A. Cunningham. See Lawrence A. Cunningham, Editor, Conversations from the Warren Buffett Symposium, 19 CARdozo L. REv. 719, 776 (1997) [hereinafter Buffett Conversations].

17 See generally Fischer Black, Noise, 41 J. Fin. 529, 529-34 (1986); J. Bradford De Long, et al., The Size and Incidence of the Losses from Noise Trading, 44 J. Fin. 681 (1989); J. Bradford De Long, et al., Noise Trader Risk in Financial Markets, 98 J. Pol. ECon. 703 (1990); Andrei Shleifer \& Lawrence H. Summers, The Noise Trader Approach to Finance, J. Econ. Persp., Spring 1990, at 19.

Although the noise trading model suggests that rational traders earn profits at the expense of noise traders, noise trading will nevertheless persist either if there is an outside supply of new noise traders, or if noise traders are less risk-averse than rational traders and so can earn superior returns by accepting risk. See generally J. Bradford De Long et al., The Survival of Noise Traders in Financial Markets, 64 J. Bus. 1 (1991).

18 See, e.g., M.C. Adam \& A. Szafarz, Speculative Bubbles and Financial Markets, 44 Oxford Econ. Papers 626 (1992) (surveying literature); William A. BarnetT et AL., Economic Complexity: Chaos, Sunspots, Bubbles, and Nonlinearity (1989); Lawrence A. Cunningham, From Random Walks to Chaotic Crashes: The Linear Genealogy of the Efficient Capital Market Hypothesis, 62 Geo. Wash. L. REv. 546 (1994). 
I believe noise theory and chaos finance both have much to offer scholars seeking to explain otherwise puzzling market phenomena. I would like to focus my discussion, however, on a third promising avenue of research I shall refer to as the "heterogeneous expectations" approach. I want to concentrate on heterogeneous expectations for three reasons. First, while the latest generation of finance theorists has paid substantial attention to the heterogeneous expectations approach, legal scholars have largely neglected it. I thus perceive an attractive opportunity to engage in what Professor Bratton has dubbed "academic arbitrage."19

My second reason for focusing on the heterogeneous expectations approach is my sense that, for many legal scholars, heterogenous expectations models may provide an especially gentle introduction to the sometimes cold and forbidding waters of postmodern finance. In a sense, the heterogeneous expectation approach is simply an elaboration or extension of the standard ECMH/CAPM story. ${ }^{20}$ Corporate scholars raised on Brealey and Myers thus may find it easier to digest than either noise theory or chaos finance.

My third reason for choosing to concentrate my discussion on the heterogeneous expectations approach is my belief that, despite its relative simplicity, the heterogeneous expectations approach to finance is an extremely powerful predictor of market behavior. As the discussion below suggests, a model of stock prices premised on investor disagreement goes a long way towards solving a number of important empirical puzzles that have plagued scholars who rely on the conventional ECMH/CAPM. ${ }^{21}$ That observation alone sug-

19 See Buffett Conversations, supra note 16, at 788.

20 Indeed, the heterogeneous expectations approach can be thought of as a necessary intermediate step between the oversimplified theoretical world of ECMH/CAPM and the complex and difficult realities of noise and chaos theory. Conventional ECMH/CAPM looks at the relationship between risky asset prices and fundamental values when all investors share homogeneous expectations for the future. See infra text accompanying notes 2223 (homogeneity). The heterogeneous expectations approach adds a degree of complexity by assuming that investors' expectations may differ. See infra text accompanying notes 25 28 (implications of heterogeneity). Noise theory takes another step to explore irrational sources of disagreement, while chaos theory examines the feedback implications of disagreement (whether rational or irrational) for price stability.

21 See Lynn A. Stout, Are Takeover Premiums Really Premiums? Market Price, Fair Value, and Corporate Law, 99 Y ALE L.J. 1235 (1990) [hereinafter Stout, Takeover Premiums] (discussing how a heterogeneous expectations approach may offer insights into the source of takeover premiums and the relationship between stock prices and fundamental values); Lynn A. Stout; Are Stock Markets Costly Casinos? Disagreement, Market Failure, and Securities Regulation, 81 VA. L. REv. 611 (1995) (discussing how heterogeneous expectations may explain investor trading behavior and the value of mandatory disclosure); Lynn A. Stout, Betting The Bank: How Derivatives Trading Under Conditions of Uncer- 
gests that academics who wish to understand the market would do well to acquaint themselves with the heterogeneous expectations approach to finance.

\section{Homogeneity AND Disagreement}

The heterogeneous expectations approach to finance begins with the assumption that people trying to predict an inherently uncertain future may have differing views about particular securities' likely risks and returns. In other words, people disagree. To the average person on the street-or average trader on the Street-the notion that people disagree may seem obvious. Yet the idea of disagreement turns out to be completely inconsistent with the conventional ECMH/CAPM.

Although the CAPM is one of the most important tools of modern finance, the theorem suffers from the following peculiarity: it assumes that all traders in the market make identical estimates of the risks and returns associated with particular securities. This assumption is readily apparent from a quick perusal of the original work of such pioneers as John Lintner and William Sharpe. Each begins with the express assumption of homogeneous expectations. $^{22}$

Recognizing that the standard CAPM assumes homogeneous expectations suggests that corporate scholars who use CAPM to predict that market prices accurately reflect a stock's intrinsic values are, in fact, relying on a tautology. After all, if all people share the same estimate of a stock's intrinsic worth, why wouldn't market

tainty Can Increase Risks and Erode Returns in Financial Markets, 21 J. CoRP. L. 53 (1995) (discussing insights of heterogeneous expectations approach for derivatives trading) [hereinafter Stout, Betting The Bank]; Lynn A. Stout, Why the Law Hates Speculators: Derivatives, Difference Contracts, and the Social Value of Antispeculation Laws (unpublished manuscript on file with author) (explaining how the heterogeneous expectations approach supports legal hostility towards speculators, including a possible explanation for speculative bubbles).

22 See John Lintner, The Valuation of Risk Assets and the Selection of Risky Investments in Stock Portfolios and Capital Budgets, 47 Rev. Econ. \& STAT. 13, 14 (1965); William F. Sharpe, Capital Asset Prices: A Theory of Market Equilibrium Under Conditions of Risk, 19 J. Fin. 425, 427 (1964).

Both Sharpe and Lintner subsequently produced work considering the effects of heterogeneity. See William F. Sharpe, Portfolio Theory and Capital Markets 104-13 (1970) [hereinafter PORTFolio THEORY]; John Lintner, The Aggregation of Investor's Diverse Judgments and Preferences in Purely Competitive Securities Markets, 4 J. FiN. \& Quantitative ANalysis 347 (1969) [hereinafter Diverse Judgements]. Jack Treynor is a third economist often credited with developing the CAPM, although his article on the subject is not published. Brealey \& MYers, supra note 4, at 180 n.9. Treynor's recent work also considers the role of heterogeneous expectations in markets. See, e.g., Jack Treynor, Bulls, Bears and Market Bubbles (unpublished manuscript on file with author). 
price reflect that consensus? The CAPM can still be quite useful for some tasks, such as describing a rational investor's attitude toward risks and returns. ${ }^{23}$ But as a justification for claiming that you can't beat the market, its reasoning is circular.

It is probably safe to say at this point that any finance theorist worth her salt now recognizes that the CAPM is a tautology. (Although this knowledge is filtering down to the legal community far more slowly, an increasing number of corporate scholars seem to recognize this as well. $)^{24}$ Indeed, a substantial body of work in finance now focuses on the problem of how asset prices are set in a world where people disagree, and offers a variety of models examining asset prices under conditions of heterogeneity. ${ }^{25}$ These models differ in many respects, and each has its own advantages. For the purposes of suggesting the potential of the heterogeneous expectations approach, however, I would like to confine my discussion to a relatively simple yet powerful model based on three

23 Among finance theorists, the term "risk" refers to fluctuations or variations in returns, including both unusual gains and unusual losses. The CAPM presumes that some sources of variation in firms' earnings are unique to individual firms, and that investors can eliminate such firm-specific (or alpha) risk simply by holding a diversified portfolio of many different stocks whose individual ups and downs cancel each other out. Other kinds of risk tend to affect all firms to a greater or lesser extent: for example, in an economic recession, everyone's business tends to suffer. Because such market (or beta) risk cannot be diversified away, risk-averse investors should demand a risk premium in the form of higher expected returns before they will be willing to hold stocks with a high degree of beta risk. Indeed, the CAPM predicts that the relationship between beta risk and returns should be linear: a stock with twice the market's level of beta risk must offer twice the market's expected return. Firms that have a high degree of alpha risk need not offer higher returns, however, because alpha risk can be diversified away. See generally BREALEY \& MYers, supra note 4 , at $173-83$.

24 For example, during the 1980s it was common for legal scholars to assert that we could rely on an efficient market to price stocks accurately, and to formulate policies based on that claim. It is my sense that this kind of argument has quietly disappeared from law journals in recent years.

25 See, e.g., Richard A. Booth, Discounts and Other Mysteries of Corporate Finance, 79 CAL. L. Rev. 1053 (1991); Diverse Judgments, supra note 22; Robert Jarrow, Heterogeneous Expectations, Restrictions on Short Sales, and Equilibrium Asset Prices, 35 J. FIN. 1105 (1980); Mordecai Kurz, Asset Prices with Rational Beliefs (Monograph No. 375, Center for Economic Policy Research, Stanford University) (Feb. 1994); Joram Mayshar, On Divergence of Opinion and Imperfections in Capital Markets, 73 AM. ECON. REv. 114 (1983); Edward R. Miller, Risk, Uncertainty, and Divergence of Opinion, 32 J. FIN. 1151 (1977); PORTfolio ThEORY, supra note 22, at 104-13; Stout, Takeover Premiums, supra note 21; Treynor, supra note 22; Hal R. Varian, Divergence of Opinion in Complete Markets: $A$ Note, 40 J. FIN. 309 (1985); Joseph T. Williams, Capital Asset Prices with Heterogeneous Beliefs, 5 J. Fin. Econ. 219 (1977).

Noise trading models can also be described as disagreement-based models. See supra notes 17, 20 (citing noise trading literature and discussing its relationship to the heterogeneous expectations approach). 
assumptions: (1) traders are risk averse; (2) they hold heterogeneous expectations; and (3) short selling is restricted.

\section{A Heterogeneous Expectations Model of Downward-SLOPING DEMAND}

Let us begin with the assumption of disagreement. In a world where investors make differing predictions of individual stocks' likely risks and returns, it seems plausible that investors' subjective expectations will be normally distributed. In other words, investors' expectations for a particular stock will fall somewhere in a range between the most pessimistic and the most optimistic, with most investors' beliefs falling near the middle of the two extremes.

Given such a range of disagreement, if a corporation decides to issue stock, who is likely to buy it? Assuming short sales are restricted, the obvious answer is: the optimists. Indeed, if investors were not risk-averse and had unlimited access to wealth, any particular corporation's shares should end up in the hands of that single individual who subjectively values the firm most highly.

In the real world, of course, investors are both risk-averse and limited in their wealth and ability to borrow. ${ }^{26}$ Thus, a super-optimistic but risk-averse investor who buys a large block of stock she perceives to be grossly underpriced will at some point begin to worry that she is putting too many of her eggs in one basket. Risk aversion will lead her to stop purchasing the stock even though she still perceives it to be significantly underpriced. ${ }^{27}$

If the corporation wants to issue a larger quantity of stock than the most-optimistic investor is willing to buy, what can the firm do? One possibility is that the firm can get the most-optimistic investor to buy more shares by lowering the issue price. This is because lowering the price allows the optimist to see the stock as an even better bargain than it was before, creating a subjective "risk premium" that the optimist believes compensates her for the increased diversifiable risk she suffers by increasing her holdings. Moreover, lowering price should also help the firm sell more shares by making the stock attractive to other relatively-optimistic investors, investors who also value the stock more highly than its newly-

26 These two characteristics are closely related: an investor with infinite wealth would have little concern for risk.

27 By devoting a large portion of her portfolio to one single stock instead of diversifying, an investor exposes herself to a higher level of firm-specific (or alpha) risk. See supra note 23 . 
reduced offering price, even if not so highly as the most-optimistic investor does.

The above analysis leads to the prediction that, even at a very high price, a firm can sell a modest quantity of stock to the subset of investors who hold the most favorable opinions of the firm's prospects. Lowering the price allows the firm to sell more shares, however, both by making the stock attractive to more investors, and by inducing existing shareholders to add to their holdings. Thus, lowering a stock's price tends to increase the quantity of that stock investors demand and are willing to hold.

This last result is highly significant because it suggests that-at least under conditions of disagreement, risk aversion, and short sales restrictions-the demand curve for any particular company's shares should be a classic downward-sloping function with price inversely correlated to the quantity of shares demanded. ${ }^{28}$ Curiously

28

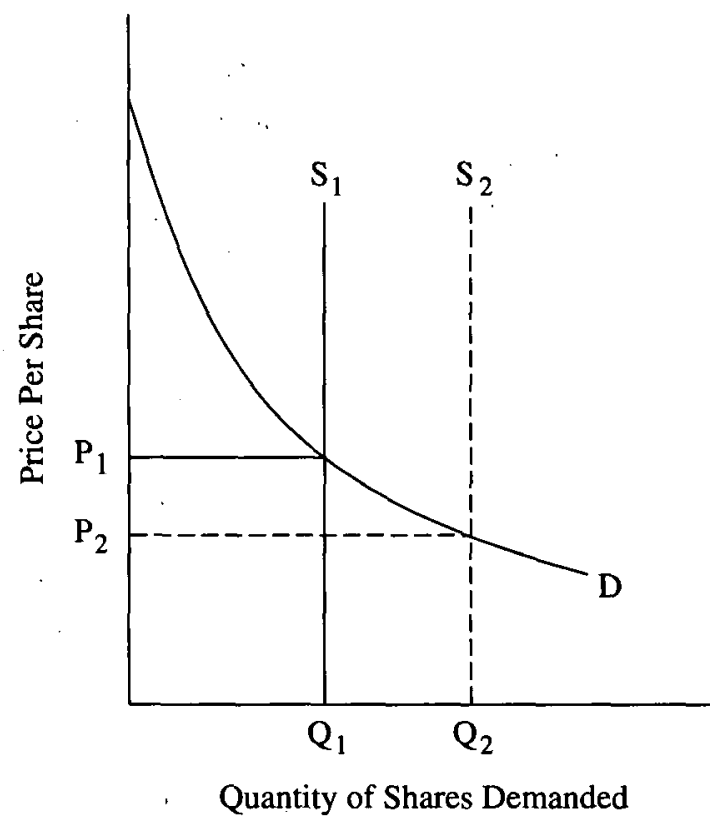

Heterogeneous investor expectations combined with risk aversion create a downward-sloping demand function for any individual stock (D). If short sales are restricted, the available supply of stock will be fixed in the short run as illustrated by vertical supply function $S_{1}$. If the company issues more shares and increases the supply of stock to $S_{2}$, equilibrium market price falls from $P_{1}$ to $P_{2}$. Conversely, repurchasing shares or paying dividends increases market price. See infra text accompanying note 49 (discussing buybacks and dividend payouts under conditions of expectations heterogeneity).

There are other events that might affect the market price of the stock even when the average investor's expectations remain unchanged. See, e.g., infra text accompanying notes 
enough, this seemingly-plausible result turns out to be completely inconsistent with the traditional ECMH/CAPM.

According to conventional theory, in an efficient market all firms' shares should be accurately priced and no firm should be a bargain relative to any other. Thus, all stocks are perfect substitutes. Perfect substitutability in turn implies that the demand curve for any individual stock should be flat: below market price investors are willing to purchase an infinite amount of shares (because all perceive the stock to be a bargain), while above market price investors refuse to purchase even a single share (because all perceive the stock as overpriced). Conversely, firms can issue or repurchase even large quantities of shares at the prevailing market price without exerting any pressure on that price. In economic terms, the CAPM predicts that demand for individual stocks should be "perfectly elastic." 29

The ECMH/CAPM prediction of perfectly elastic demand raises a number of troubling questions for academics who rely on conventional finance. As the discussion below suggests, investors and stock markets often behave in ways that seem difficult, if not impossible, to reconcile with the notion of perfectly elastic demand. Many otherwise puzzling market phenomena begin to make sense, however, under a heterogeneous expectations model of stock pricing. To the scholar willing to move beyond the conventional ECMH/CAPM, and willing to assume that investors disagree and the demand for individual securities is downward-sloping, a number of financial mysteries are revealed.

\section{Mystery No. 1: Why Don't Investors Fully Diversify?}

Conventional finance theory teaches investors to eliminate firm-specific (or alpha) risk from their portfolios by diversifyingthat is, by buying stocks in many different companies whose individual risks tend to cancel each other out. ${ }^{30}$ An investor can reduce the impact of changing fuel prices on her portfolio, for

\footnotetext{
38-42 (discussing how increasing uncertainty regarding the company's future which increases the dispersion of investors' expectations might raise prices); infra text accompanying notes 36-37 (discussing how increasing public awareness of the company which increases the pool of potential investors might raise prices by shifting the demand curve outward); infra note 38 (discussing how a listing on the S\&P 500 index which induces purchases by indexed mutual funds might also raise prices by shifting the demand curve outward).

29 See Brealey \& MYers, supra note 4, at 345-46 (discussing ECMH/CAPM prediction of perfectly elastic demand for stocks).

30 See supra note 23 (discussing alpha risk).
} 
example, by buying stocks in both oil companies (whose share prices tend to rise with fuel prices) and airlines (whose stocks tend to fall when fuel prices rise). Because an efficient market prices all stocks accurately, such diversification should reduce alpha risk without sacrificing return. Thus, modern portfolio theory counsels investors to diversify their investments.

Curiously, many apparently rational investors seem to ignore this advice by maintaining portfolios that are heavily weighted toward a relatively small number of companies. Warren Buffett and Charlie Munger provide an archetypal example: they go so far as to recommend concentration rather than diversification as the best strategy for investing. ${ }^{31}$ To scholars who rely on conventional ECMH/CAPM, such behavior seems puzzling indeed. ${ }^{32}$ After all, isn't the investor who fails to diversify passing up a cost-free opportunity to reduce risk?

Perhaps Buffett, Munger, and other investors who don't diversify simply haven't read Brealey and Myers. However, the heterogeneous expectations model suggests another explanation for their behavior. Under the conventional, homogeneous expectationsbased version of the ECMH/CAPM, all investors perceive all stocks as perfect substitutes, and diversification accordingly is assumed not to carry a cost in the form of reduced returns. Under the heterogeneous expectations approach, however, investors who disagree with market prices are likely to see some stocks as bargains and others as too pricey. Concentration thus becomes not only an acceptable but a preferred strategy to the investor who believes that one stock offers a better buy than another.

\section{Mystery No. 2: Why Do Target Company Shareholders Appear to Capture All the Gains in Corporate TAKEOVERS?}

A second mystery of corporate finance that has captured many legal scholars' attention is the phenomenon of large takeover premiums. In a typical corporate acquisition, the bidding company will pay $25 \%, 50 \%$, or even $75 \%$ over the earlier prevailing market price for the target's shares. ${ }^{33}$ This pattern seems puzzling, for ac-

31 See Lawrence A. Cunningham, Compilation, The Essays of Warren Buffett: Lessons for Corporate America, 19 CARdozo L. REv. 1, 75 (1997) [hereinafter Buffett Essays].

32 See Buffett Conversations, supra note 16, at 787-94 (discussing puzzle).

33 See Stout, Takeover Premiums, supra note 21, at 1235, 1256. While the shareholders in target firms seem to reap huge gains in takeovers, on average the bidder's share price usually does not rise or fall significantly. See id. at 1260. 
cording to the ECMH/CAPM, the demand curve for the target company's stock should be flat. Thus, takeover bidders should be able to purchase even very large blocks of their targets' stock without paying significant premiums. After all, if investors regard all stocks as perfect substitutes, target shareholders should be willing to jump ship even if offered only a dollar over market price.

Legal scholars who rely on the conventional ECMH/CAPM approach to finance accordingly have tended to regard takeover premiums as a somewhat striking phenomenon. Indeed, more than one grove of trees has been sacrificed in the attempt to explain them. ${ }^{34}$ The puzzle of takeover premiums is only a puzzle, however, if the demand curve for a target company's stock is flat. If the demand curve for the target's stock is downward-sloping, an easy and elegant explanation for premiums emerges.

When investors disagree and the demand curve for a target's stock is downward-sloping, the market price for a single share of the target company will be set by the subjective valuation of the most pessimistic member of the optimistic subset of investors who choose to hold shares in that company. A buyer who only wants to purchase a single share only needs to offer a price sufficient to satisfy this marginal, relatively pessimistic shareholder. A takeover bidder who wants to purchase a very large number of shares, however, must also be prepared to deal with more optimistic shareholders who value their shares more highly than the marginal shareholder does. Thus, to acquire a controlling interest- $51 \%$, $70 \%$, or even $100 \%$ - a takeover bidder must work her way up a sloping demand function, paying ever higher prices to acquire more shares. ${ }^{35}$

The heterogeneous expectations model of downward-sloping demand consequently predicts that any successful takeover bidder

34 See, e.g., Bernard Black, Bidder Overpayment in Takeovers, 41 STAN. L. Rev. 597 (1989); John C. Coffee, Jr., The Uncertain Case for Takeover Reform: An Essay on Stockholders, Stakeholders and Bust-Ups, 1988 WIs. L. Rev. 435; Reinier Kraakman, Taking Discounts Seriously: The Implications of "Discounted" Shares Prices as An Acquisition Motive, 88 Colum. L. Rev. 891 (1988); Dale Arthur Oesterle, Revisiting the Anti-Takeover Fervor of the '80s Through the Letters of Warren Buffett: Current Acquisition Practice Is Clogged by Legal Flotsam from the Decade, 19 Cardozo L. Rev. 565 (1997); Roberta Romano, A Guide to Takeovers: Theory, Evidence, and Regulation, 9 YALE J. on REg. 119 (1992); Stout, Takeover Premiums, supra note 21.

35 The heterogeneous expectations approach thus explains not only why bidders pay premiums, but also why the amount of the premium seems to be directly related to the percentage of the target's stock the bidder hopes to acquire. See Stout, Takeover Premiums, supra note 21, at 1256 (citing evidence that as bidders seek to acquire larger percentages of targets' stock, they pay larger premiums). 
inevitably must pay a price significantly higher than the market price for a single share of the target's stock. Far from being peculiar phenomena, large takeover premiums are revealed as the natural consequence of acquiring a large block of shares under conditions of downward-sloping demand.

\section{Mystery No. 3: - The Neglected Firm Effect and Similar Market "Anomalies"}

A third mystery that has long troubled efficient market theorists is the problem of how to explain empirically observed market "anomalies," that is, classes of stocks that consistently produce either higher, or lower, risk-adjusted returns than the market as a whole. One typical example is the "neglected firm" effect. Studies have shown that stocks of companies that are relatively unknown to the public and that do not receive much attention from financial analysts-so-called neglected firms-tend to trade at depressed prices relative to better known firms whose names are on every investor's lips. ${ }^{36}$ As a result, a portfolio of relatively cheap neglected stocks will produce superior returns over time compared to a portfolio of pricier, better known securities.

Scholars who rely on conventional finance theory find this result difficult to explain. After all, the ECMH/CAPM predicts that in an efficient market, no stock or class of stocks should offer a bargain relative to any other. The existence of a consistently underpriced class of stocks thus violates one of the most fundamental tenets of efficient market theory.

Yet the neglected firm effect and a variety of similar market anomalies make sense under a heterogeneous expectations model of stock pricing. Consider the example of the neglected firm. The more obscure a firm is, the smaller the number of people who know about it. The fewer people who know about a company, the smaller the pool from which it must draw its subset of relatively optimistic investors. Thus, where a high profile company known to a large pool of potential investors may be able to find enough super-optimists to buy all its shares, a relatively unknown company that wants to issue the same amount of stock may have to sell to the merely optimistic as well. The stocks of neglected firms consequently tend to trade at depressed prices relative to the stocks of better known firms with the same likely risks and returns. Voilà-

36 See James Lindgren, Telling Fortunes: Challenging the Efficient Markets Hypothesis By Prediction, 1 S. CAL. INTERdisc. L.J. 7, 17 n.47 (1992) (listing studies). 
the heterogeneous expectations model predicts that neglected firms should offer a bargain to savvy investors. ${ }^{37}$

A second kind of company that should offer a bargain is the boring firm. To understand this point, it is important to recognize that exciting firms are exciting because their prospects are highly uncertain (will Netscape come to dominate the market for Internet search engines, or will it sink into insolvency?). When a firm's future is highly uncertain, the bell curve of investors' subjective expectations is likely to stretch over a wider range. Thus, the optimistic tail of investors who set market price may be not just optimistic, but wildly optimistic. Conversely, investors' opinions about a boring firm will be more uniform, and a market price set by the most optimistic subset will lie closer to the average investor's valuation. The net result is that boring firms should be underpriced relative to exciting firms.

The above analysis provides a theoretical solution to at least two more market anomalies: the "low P/E" effect, and the "high beta" effect. ${ }^{38}$ Studies have shown that portfolios comprised of stocks that trade at relatively low price-to-earnings $(\mathrm{P} / \mathrm{E})$ ratios tend to outperform the market portfolio. ${ }^{39}$ This result makes sense if low $\mathrm{P} / \mathrm{E}$ firms tend to be boring firms, and high $\mathrm{P} / \mathrm{E}$ firms tend to be exciting firms whose optimistic shareholders expect earnings to increase dramatically in the near future. Similarly, the heterogeneous expectations approach can explain otherwise-puzzling evidence that firms with high beta risk-that is, companies whose stocks are extremely sensitive to nondiversifiable, market-wide fluctuations in market prices-offer investors lower returns than the market as a whole. $^{40}$ This result is a slap in the face of the standard ECMH/ CAPM: after all, one of its most fundamental axioms is that stocks with high beta risk must offer higher returns to attract risk-averse

37 See Stout, Takeover Premiums, supra note 21, at 1256-57 (discussing heterogeneous expectations and downward-sloping demand as explanation for neglected firm effect).

38 Yet another market anomaly that can be explained by downward-sloping investor demand for stocks is the "S\&P 500" effect. Studies have shown that when a company's stock is added to the S\&P 500 index, share price tends to rise. See, e.g., Andrei Shleifer, Do Demand Curves for Stocks Slope Down?, 41 J. Fin. 579 (1986). This result is somewhat puzzling under the conventional ECMH/CAPM, because the S\&P 500 list is compiled without regard to the quality of the firms listed. Thus listing should not carry any new information, good or bad, to investors. Index listing does, however, trigger purchases by "indexed" mutual funds that specialize in holding only S\&P 500 securities. If such an increase in the pool of investors interested in holding a stock shifts a downward-sloping demand function outward, the net result is to raise market price. See id.

39 See Lindgren, supra note 36, at 16 n.41 (listing studies).

40 See Miller, supra note 25 , at $1157,1167-68$ (citing studies). 
investors. ${ }^{41}$ Yet the high-beta effect makes sense if high-beta companies are not only risky but exciting (that is, uncertain) companies. $^{42}$

\section{Mystery No. 4: Why Do Corporate Managers Believe Stock Buybacks and Dividend Payouts Support Share Prices?}

Corporate managers often use firm funds to repurchase outstanding stock from shareholders in the belief that such a strategy will raise, or at least prevent a decline in, the market price of the firm's stock. Conversely, issuing new shares is thought to depress market prices. ${ }^{43}$ A related belief commonly found in the corporate culture is that regular dividend payments prop up stock prices. ${ }^{44}$ This symmetry reflects the fact that in at least one important respect, buybacks and dividends are equivalent strategies: both pay out some of the firm's cash either to present shareholders (in the case of dividends) or to former shareholders (in the case of buybacks).

To scholars who studied finance in the 1970s and early 1980s, these beliefs must surely seem somewhat peculiar. According to the Miller-Modigliani theorem-a close cousin of the ECMH/ CAPM-a firm's decision to pay dividends or repurchase stock ought to have no effect, positive or negative, on share prices. ${ }^{45}$ Why then do corporate managers continue to believe that dividend policy and stock repurchase programs matter? ${ }^{46}$

41 See supra note 23 and accompanying text (discussing relationship between risk and return under standard CAPM).

42 This observation relies on the crucial distinction between risk and uncertainty. See generally Stout, Betting The Bank, supra note 21, at 59. Economists use the word "risk" to refer to situations where the outcome of an event is unknown, but the probabilities of possible outcomes are known. Thus, a coin toss is risky: while we do not know if the coin will come up heads or tails, we know the probability of either event is $50 \%$. In contrast, "uncertainty" exists in situations where neither the outcome nor the probabilities of possible outcomes are fully known, so that individuals' subjective probability estimates may differ.

43 See Brealey \& Myers, supra note 4, at 345-46 (discussing market participants believe issuing and repurchasing stock changes price).

44 See William W. Bratton, Dividends, Noncontractibility, and Corporate Law, 19 CARDozo L. REv. 409, 418 (1997).

45 See generally BREALEY \& MYers, supra note 4, at 423-24 (discussing the MillerModigliani theorem and the irrelevance of dividend policy).

46 Substantial empirical evidence supports this view. See, e.g., Laurie Simon Bagwell, Dutch Auction Repurchases: An Analysis of Shareholder Heterogeneity, 47 J. FIN. 71 (1992). 
In the attempt to resolve this conflict between theory and practice, some corporate scholars have suggested that regular dividends support share prices because they overcome information problems by providing distrustful shareholders with evidence of corporate profits in the form of cold, hard cash, rather than a reported increase in retained earnings in the company's books. ${ }^{47}$ Others argue that dividends and buybacks respond to shareholder concerns over agency costs by signalling that management is not indulging in a costly empire-building strategy. ${ }^{48}$ Both claims seem plausible, and both may play some part in explaining why managers believe that buybacks and dividends prop up prices. Yet the heterogeneous expectations approach offers an alternative and more straightforward explanation.

When a corporation buys back shares, it reduces the supply of its stock available on the open market. If the demand curve for the firm's stock is downward-sloping, the net result is to liquidate the interests of the less-optimistic shareholders who comprise the lower portion of the curve. This naturally and inevitably increases the marginal price for the company's shares. ${ }^{49}$ Similarly, a firm that pays cash dividends reduces the investment interest of each of its current shareholders. Because this reduces their firm-specific risk, it increases their willingness to keep, or even add to, their shareholdings, again raising the marginal price for shares.

The heterogeneous expectations approach consequently suggests that corporate managers believe that buybacks and dividends alone raise prices because they do. This result need not depend on informational asymmetries or shareholder concern over agency costs: rather, it is the natural and unescapable consequence of restricting the supply of shares in the face of a downward-sloping demand function.

\section{Mystery No. 5: How Do Some Investors And Fund Managers Consistently Beat the Market?}

The fifth and final mystery I want to discuss is, in a sense, the principal subject of this conference: how do some fund managers, Buffett and Munger chief among them, so consistently beat the market?

47 See Bratton, supra note 44 , at 418.

48 See id.

49 See supra note 28 and accompanying text (illustrating relationship between stock supply and market price under conditions of downward-sloping demand). 
One possible answer is, they really don't. Stocks are naturally volatile instruments, and random chance ensures that the typical portfolio manager will enjoy superior returns in some years and losses in others. A few fortunate managers may even experience a string of good years-the market's equivalent of flipping a coin ten times in a row and having it come up heads each time. Perhaps Berkshire Hathaway's success can be traced to such random luck.

But while the rules of chance admit the possibility of a string of winners, the longer a winning streak persists, the more statistically unlikely it becomes that credit should be laid at Lady Luck's door. Studies of the hot hand effect have concluded that some money managers' winning abilities defy the iron laws of probability. ${ }^{50}$ Similarly, Berkshire Hathaway's record of decades of superior performance is also beginning to look like something more than mere chance.

Once again, the heterogeneous expectations approach offers a potential solution to the mystery of Berkshire Hathaway. The heterogeneous expectations approach suggests that Buffett and Munger claim they can beat the market because they can. The reason can be traced to market anomalies such as the neglected firm effect examined earlier. If, as the heterogeneous expectations approach suggests, certain classes of stocks trade at lower prices relative to their expected risks and returns than other stocks, the clever manager who refuses to accept the conventional wisdom of the ECMH/ CAPM and seeks out such underpriced companies should, over time, be able beat the market's return. This is exactly what Buffett and Munger purport to do, and the heterogeneous expectations approach to finance supports their claim.

\section{Conclusion: Some Lessons for Corporate Scholars From WARREN BUFFETT}

As this brief survey suggests, a model of stock pricing premised on the plausible notions that investors disagree and that the demand curves for individual stocks are downward-sloping can solve a number of the puzzles that have long troubled scholars who rely on the homogeneity-based theories of "modern" finance. Indeed, my discussion has touched upon only a few examples: other financial mysteries as well can be solved using a heterogeneous expectations approach. ${ }^{51}$ Rather than providing an exhaustive catalog of possibilities, however, I would like to close by emphasizing why

50 See studies cited supra note 12.

51 See, e.g., articles cited supra note 21. 
the time has come for corporate scholars to swallow hard and dive into the sometimes-murky waters of postmodern finance. In brief: because it works.

During the past two decades, an extensive body of empirical evidence has accumulated indicating that, in many situations, investors and securities markets simply refuse to behave the way the ECMH/CAPM predicts they should. Indeed, finance scholars have found so many exceptions to efficient market behavior that the exceptions appear to be swallowing the rule. Postmodern alternatives to the conventional ECMH/CAPM-including noise theory, chaos theory, and particularly heterogeneous expectations theory-offer hope to those who want to be able to understand and predict the markets we've got, rather than the elegant but unrealistically simplistic markets described by Brealey and Myers.

Accordingly, scholars who study financial markets now face a choice. To those of us who were raised on Brealey and Myers, postmodern financial theory may seem disconcertingly unfamiliar. Yet, if postmodern approaches to finance often are more accurate predictors of actual market behavior, academics who recognize that reality and incorporate the lessons of postmodern finance into their work will often be able to produce results that are both positively and normatively more correct than those that can be achieved using the conventional, homogeneity-based ECMH. To paraphrase Warren Buffett, we can either hew to the conventional ECMH/CAPM and be neatly and precisely wrong, or we can heed the lessons of postmodern finance, and be messily and approximately right. ${ }^{52}$

As Warren Buffett and Charlie Munger have shown us, a willingness to study financial markets as they actually exist can produce substantial rewards. Although academics' rewards may be intellectual rather than monetary, they are no less valuable.

52 See Buffett Essays, supra note 31, at 76 ("[1]t is better to be approximately right than precisely wrong."). 